\title{
PENGARUH LINGKUNGAN KERJA FISIK DAN NON FISIK TERHADAP KINERJA PEGAWAI KEMENTERIAN AGAMA KOTA PALU
}

\author{
Megawati \\ Bakri Hasanuddin \\ Yobert Kornelius \\ Program Studi Manajemen, Fakultas Ekonomi, Universitas Tadulako \\ Email: Megawatiindrajaya15@gmail.com, yoberthkornelius@yahoo.com
}

\begin{abstract}
This study aims to determine the effect of Physical Work Environment and Non Physical Work Environment on Employee Performance at the Office of the Ministry of Religious Affairs of Palu City. The method used is an associative method. The type of data used in this study is the qualitative and quantitative data while the data sources used are primary and secondary data. Data analysis technique used is Multiple Linear Regression Analysis. The result of hypothesis analysis and testing can be concluded that: (1) based on the regression test results obtained Sig.F of 0,000 <0.05, which can be interpreted that the variables of Physical Work Environment and non physical work environment simultaneously affect the performance variables. (2) based on the regression test results obtained the physical work environment variable has significance level $t$ sig. $(0,000)<\alpha(0.05)$ and non-physical work environment has a significance level of $t$ sig. $(0.000)<\alpha(0,05)$, so the variable of physical work environment and non working physical environment partially influence to employee performance.
\end{abstract}

Keywords: Physical Work Environment, Non Physical Work Environment,Performanc

\begin{abstract}
ABSTRAK
Penelitian ini bertujuan untuk mengetahui Pengaruh Lingkungan Kerja Fisik dan Non Fisik Terhadap Kinerja Pegawai Pada Kantor Kementerian Agama Kota Palu. Metode yang digunakan adalah metode assosiatif. Jenis data yang digunakan dalam penelitian ini adalah data kualitatif dan kuantitatif sedangkan sumber data yang digunakan adalah data primer dan sekunder. Teknik analisis data yang digunakan adalah Analisis Regresi Linear Berganda. Hasil analisis dan pengujian hipotesis dapat disimpulkan bahwa: (1) berdasarhan hasil uji regresi diperoleh Sig.F sebesar 0,000 $<0,05$, yang dapat diartikan bahwa variabel lingkungan kerja fisik dan non fisik secara serempak berpengaruh terhadap variabel kinerja. (2) berdasarkan hasil uji regresi diperoleh variabel lingkungan kerja fisik memiliki tingkat signifikansi t sig. $(0,000)<\alpha(0,05)$ dan variabel lingkungan kerja non fisik memiliki tingkat signifikansi t sig. $(0.000)<\alpha(0,05)$, sehingga variabel lingkungan kerja fisik dan lingkungan kerja non fisik secara parsial berpengaruh terhadap kinerja pegawai.
\end{abstract}

Kata kunci: Lingkungan Kerja Fisik, Lingkungan Kerja Non Fisik, Kinerja

\section{PENDAHULUAN}

Pelaksanaan pembangunan pada dasarnya merupakan suatu usaha dalam rangka mewujudkan citacita bangsa, yaitu mewujudkan masyarakat yang adil dan makmur serta merata antara materil dan spiritual. Agar pembangunan tersebut dapat tercapai sangat diperlukan partisipasi aktif dari seluruh lapisan masyarakat. Salah satu bentuk partisipasi tersebut adalah dengan mengabdikan diri kepada organisasi pemerintah maupun swasta. Setiap upaya untuk melaksanakan pembangunan agar tercapai sesuai tujuan tentunya diperlukan sumber daya manusia yang berkualitas, yaitu bekerja dengan usaha yang keras, sungguh-sungguh, dan memiliki kegairahan bekerja yang tinggi. Pengelolaan terhadap sumber daya manusia sangatlah penting guna memeperoleh kinerja pegawai, seperti yang diharapkan 
dalam rangka mencapai visi dan misi serta tujuan organisasi. Oleh karena itu, setiap organisasi berusaha meningkatkan kinerja dengan upaya memperhatikan faktor yang mempengaruhi, demikian pula halnya pada instansi pemerintahan.

Menurut Nitisemito (2000:183), lingkungan kerja adalah segala sesuatu yang ada disekitar para pekerja yang dapat mempengaruhi dirinya dalam menjalankan tugas-tugas yang diembannya, untuk mengoptimalkan produktivitas para pegawai harus tercipta lingkungan kerja yang kondusif sebagai prasyarat peningkatan kinerja pegawai secara maksimal.

Usman (2009), menyebutkan bahwa kinerja merupakan suatu usaha yang dilakukan dalam rangka mencapai prestasi kerja yang lebih baik dalam satuan waktu yang telah ditentukan dengan kriteria tertentu pula. Satuan waktu yang ditentukan bisa satu tahun, dua tahun, bahkan lima tahun atau lebih. Mangkunegara (2005), menjelaskan bahwa kinerja adalah prestasi atau kemampuan yang dicapai oleh seseorang dalam melaksanakan tugasnya sesuai dengan tanggung jawab yang diberikan kepadanya dan sesuai dengan standar kerja yang ditetapkan untuk mencapai suatu tujuan didalam organisasi,.

Berdasarkan hasil observasi yang dilakukan pada tanggal 24 Februari 2017 pukul 09:10 Wita, bahwa lingkungan kerja di Kementerian Agama Kota Palu dilihat dari lingkungan kerja fisik menunjukan lingkungan kerja yang cukup memadai, hal ini ditandai dengan tersedianya perlengkapan dan fasilitas kerja. Namun, terlihat kondisi ruang kerja yang tidak memenuhi kapasitas sebagai penyimpanan berkas data-data pegawai maupun penataan posisi letak peralatan kerja mengakibatkan ruang gerak yang terbatas, serta pengawasan yang diterapkan dari atasan terhadap bawahan sangat kurang sehingga pegawai selalu membiarkan pekerjaan yang seharusnya dikerjakan yaitu lalai dalam mengerjakan suatu pekerjaan misalnya untuk memperhatikan data pegawai. Hal ini juga membuktikan bahwa kualitas kinerja pegawai tidak terampil dalam menyelesaikan tugas, serta kinerja pegawai dalam menyelesaikan tugas belun tepat waktu.

Berdasarkan uraian diatas maka penulis tertarik untuk melakukan penelitian dengan judul "Pengaruh Lingkungan Kerja Fisik dan Non Fisik terhadap Kinerja Pegawai Pada Kantor Kementerian Agama Kota Palu". Berdasarkan uraian diatas juga, maka dapat di identifikasi masalah penelitian sebagai berikut: 1) apakah lingkungan kerja fisik dan non fisik secara serempak berpengaruh positif dan signifikan terhadap kinerja pegawai pada Kantor Kementerian Agama Kota Palu, 2) apakah lingkungan kerja fisik berpengaruh positif dan signifikan terhadap kinerja pegawai pada Kantor Kementerian Agama Kota Palu, 3) apakah lingkungan kerja non fisik berpengaruh positif dan signifikan terhadap kinerja pegawai pada Kantor Kementrian Agama Kota Palu; dengan tujuan: (1) Untuk mengetahui dan menganalisis apakah lingkungan kerja fisik dan non fisik secara serempak berpengaruh positif dan signifikan terhadap kinerja pegawai pada Kantor Kementerian Agama Kota Palu,(2) Untuk mengetahui dan menganalisis apakah Lingkungan Kerja Fisik berpengaruh positif dan signifikan terhadap Kinerja Pegawai pada Kantor Kementerian Agama Kota Palu, (3) Untuk mengetahui dan menganalisis apakah Lingkungan Kerja Non Fisik berpengaruh positif dan signifikan terhadap Kinerja Pegawai pada Kantor Kementerian Agama Kota Palu.

\section{TINJAUAN PUSTAKA}

Saydam (2002:226), mendefinisikan lingkungan kerja sebagai "keseluruhan sarana prasarana kerja yang ada di sekitar pegawai yang sedang melaksanakan pekerjaan yang dapat mempengaruhi pekerjaan itu sendiri". Menurut Lewa dan Subono (2005:235), bahwa lingkungan didesain sedemikian rupa agar dapat tercipta hubungan kerja yang mengikat pekerjaan dengan lingkungan.

Hasibuan (2012) mendefinisikan lingkungan kerja fisik sebagai lingkungan kerja yang bersfat nyata, menyangkut kondisi tempat atau ruangan dan kelengkapan material atau peralatan yang diperlukan untuk bekerja. Lima faktor yang berhubungan dengan kondisi lingkungan kerja fisik 
menurut Tohardi (2002:137-134) yaitu:(1) Kondisi penerangan di tempat kerja; (2) Keadaan ruangan di tempat kerja; (3) Masalah kebisingan di tempat kerja; (4) Peredaran udara di tempat kerja; (5) Masalah pewarnaan di tempat kerja Menurut Sihombing (2004), lingkungan kerja non fisik mencakup hubungan kerja yang terbentuk di instansi antara atasan dan bawahan serta antara sesama pegawai. Beberapa macam lingkuan kerja yang bersifat non fisik menurut Wursanto (2009), pada penelitian Sukamto, Masjaya, Riady (2013), disebutkan yaitu ; (1) Adanya perasaan aman dari para pegawai dalam menjalankan tugasnya; (2) Adanya loyalitas yang bersifat dua dimensi; (3) Adanya persaan puas dikalangan pegawai. Menurut Ishak dan Tanjung (2003), manfaat lingkungan kerja adalah menciptakan gairah kerja, sehingga produktivitas dan prestasi kerja meningkat. Menurut Mangkunegara (2004:67), yang dimaksud kinerja (performance) adalah hasil kerja secara kualitas dan kuantitas yang dicapai oleh seseorang karyawan dalam melaksanakan tugasnya sesuai dengan tanggung jawab yang diberikan kepadanya. Menurut Mangkunegara (2001:68) bahwa karakterikstik orang yang mempunyai kinerja tinggi adalah sebagai berikut; (1) Memiliki tanggung jawab pribadi yang tinggi;(2) Berani mengambil dan menanggung resiko yang dihadapi; (3) Memiliki tujuan yang realistis; (4) Memiliki rencana kerja yang menyeluruh dan berjuang untuk merealisasi tujuannya; (5) Memanfaatkan umpan balik (feed back) yang konkrit dalam seluruh kegiatan kerja yang dilakukannya;(6) Mencari kesempatan untuk merealisasikan rencana yang telah diprogramkan.

Albert dalam Handoko (1996:294) mengungngkapkan beberapa faktor yang dapat mempengaruhi kinerja yang mana disebutkan adalah faktor eksternal yaitu: "kondisi di luar organisasi maupun yang ada di dalam organisasi yang berupa faktor di luar diri anggota. Faktor-faktor itu yakni; keadaan organisasi lain, kondisi lingkungan kerja yang berupa kondisi fisik maupun kondisi sosial organisasi yang bersangkutan serta tuntutan anggota masyarakat diluar organisasi". Penelitian Mashul Akbar Sukamto, Masjaya, M. Gunthar Riady (2013) dengan judul penelitian "Pengaruh Lingkungan Kerja Fisik dan Non Fisik terhadap Kinerja Pegawai pada Badan Ketahanan Pangan dan Pelaksanaan Pangan Penyuluh Daerah Kota Samarinda" dan hasilnya mengatakan bahwa variabel lingkungan non fisik (X2) terhadap kinerja (X2) pegawai, berpengaruh positif dan signifikan secara langsung terhadap kinerja pegawai

\section{Lingkungan Kerja Fisik (X1)}

1. Penerangan di tempat kerja

2. Keadaan ruangan

3. Kebisingan ditempat kerja

4. Peredaran udara di tempat kerja

5. Pewarnaan di tempat

Kerja

(Tohardi 2002:137)

Lingkungan Kerja Non Fisik (X2)

1.Hubungan kerja antara atasan dan bawahan. 2.Hubungan kerja antara sesama pegawai

(Sihombing ,2004)

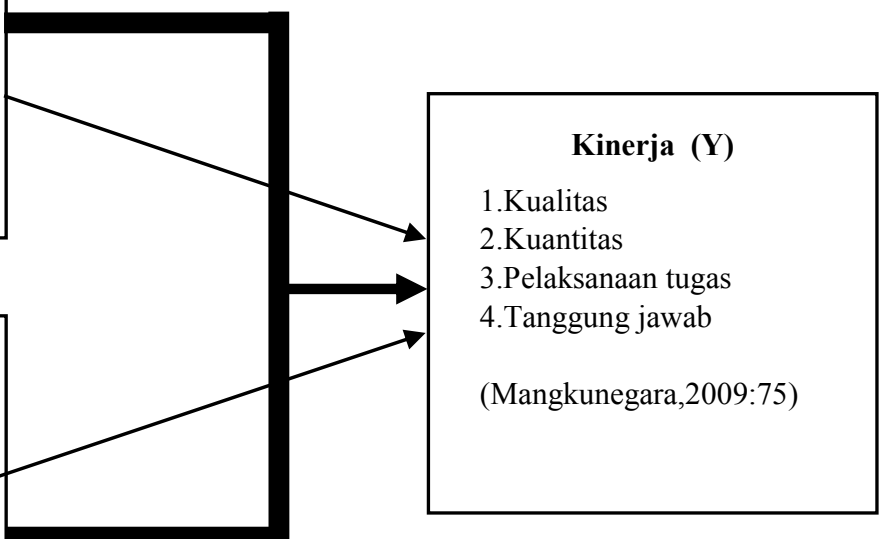

1.Kualitas

2.Kuantitas

3.Pelaksanaan tugas

(Mangkunegara,2009:75)

\section{Gambar 1. Kerangka Pemikiran}


Keterangan:

$\longrightarrow$ : Pengaruh secara serempak

$\longrightarrow$ : Pengaruh secara parsial

\section{Hipotesis Penelitian}

Adapun hipotesis dalam penelitian ini sebagai berikut : (1) Variabel lingkungan kerja fisik dan non fisik secara serempak berpengaruh positif dan signifikan terhadap kinerja Pegawai Kantor Kementerian Agama Kota Palu: (2) Variabel lingkungan kerja fisik berpengaruh positif dan signifikan terhadap kinerja Pegawai Kantor Kementerian Agama Kota Palu.(3) Variabel lingkungan kerja non fisik berpengaruh positif dan signifikan terhadap kinerja Pegawai Kantor Kementerian Agama Kota Palu.

\section{METODE PENELITIAN}

Jenis penelitian yang digunakan dalam penelitian ini adalah deskriptif dan kuantitatif. Menurut Sugiyono (2012:147) metode deskriptif adalah metode yang digunakan untuk mendeskripsikan atau menggambarkan data yang terkumpul sebagaimana adanya tanpa bermaksud membuat kesimpulan yang berlaku untuk umum.

Menurut Sugiyono (2013:38), objek (variabel penelitian) adalah segala sesuatu yang berbentuk apa saja yang ditetapkan oleh peneliti untuk dipelajari sehingga diperoleh informasi tentang hal tersebut, kemudian ditarik kesimpulan. Adapun objek dalam penelitian ini adalah Lingkungan Kerja Fisik, Lingkungan Kerja Non Fisik dan Kinerja Pegawai pada Kantor Kementerian Agama Kota Palu.

Jenis data yang digunakan dalam penelitian ini adalah data kualitatif dan data kuantitatif. Sumber data yang digunakan dalam penelitian ini adalah data primer dan data sekunder. Teknik pengumpulan data yang digunakan dalam penelitian ini adalah observasi, wawancara, kuesioner (angket) dan dokumentasi. Populasi dalam penelitian ini adalah seluruh pegawai Kantor Kementerian Agama Kota Palu yang berjumlah 102 orang.

Rumus yang digunakan untuk menentukan besarnya ukuran sampel yang akan diteliti dalam penelitian ini adalah dengan menggunakan cara Slovin. Pengambilan sampel ini menggunakan taraf kesalahan sebesar $10 \%$. Adapun rumus yang digunakan adalah sebagai berikut:

$$
n=\frac{\mathrm{N}}{1+\mathrm{N}(e)^{2}}
$$

\section{Keterangan:}

$\mathrm{n} \quad=$ ukuran sampel

$\mathrm{N}=$ ukuran populasi

$\mathrm{e}=$ persen kelonggaran/ketidaktelitian karena kesalahan pengembalian sampel yang masih dapat ditolerir. Adapun tingkat kesalahan $(\mathrm{e}=10 \%)$, sehingga dapat diperoleh jumlah sampel dalam penelitian adalah :

$\mathrm{n}=\frac{102}{1+102(0,1)^{2}}$

$\mathrm{n}=\frac{102}{2,02}$

$\mathrm{n}=50,49=50$

Perhitungan di atas menunjukan sampel penelitian sebanyak 50. Jumlah anggota sampel bertingkat (berstrata) dilakukan dengan teknik proportional stratified random sampling.Adapun variabel yang digunakan dalam penelitian ini terdiri dari variabel independen (bebas) dan variabel terkait dependen (terkait). Variabel independen pada penelitian ini yaitu lingkungan kerja fisik (X1), lingkungan kerja 
non fisik (X2), sebagai variabel bebas/independen (variabel $\mathrm{X}$ ), dan kinerja sebagai variabel terkait/dependen (variabel Y).

Menurut Sugiyono (2016:102), Instrumen penelitian adalah suatu alat yang digunakan mengukur fenomena alam maupun sosial yang diamati. Alat ukur yang digunakan dalam penelitian ini, dikenal dengan nama instrumen penelitian yang disusun dalam bentuk kuesioner dengan menggunakan skala Likert. Pengujian instrumen penelitian ini menggunakan uji validitas dan uji reabilitas. Sebuah instrumen dikatakan valid apabila memiliki koefisien korelasi (corrected item total correlation) $r \geq 0,3$ sebaliknya apabila koefisien korelasi $\mathrm{r}<0,3$ maka dikatakan tidak valid (Ghozali,2011:52). Uji reliabilitas dapat dilakukan dengan menggunakan bantuan program SPSS, yang akan memberikan fasilitas untuk mengukur reliabilitas dengan uji statistik Cronbanch Alpha ( $\alpha$ ). Suatu konstruk atau variabel dikatan reliabel jika memberikan nilai Crobanch Alpha >0,70 (Ghozali, 2011:47). Hasil pengujian dapat terlihat pada tabel berikut:

Tabel 2 Hasil Uji Validitas Variabel Lingkungan Kerja Fisik (X1)

\begin{tabular}{|c|c|c|c|c|}
\hline Variabel & Indikator & No. Item & Corrected Item-Total Correlation & Status Item \\
\hline \multirow{15}{*}{$\begin{array}{c}\text { Lingkungan Kerja Fisik } \\
\text { (X1) }\end{array}$} & \multirow{3}{*}{ Penerangan } & 1 & 0.734 & Valid \\
\hline & & 2 & 0.850 & Valid \\
\hline & & 3 & 0.773 & Valid \\
\hline & \multirow{3}{*}{ Keadaan ruangan } & 4 & 0.881 & Valid \\
\hline & & 5 & 0.849 & Valid \\
\hline & & 6 & 0.832 & Valid \\
\hline & \multirow{3}{*}{ Kebisingan } & 7 & 0.368 & Valid \\
\hline & & 8 & 0.685 & Valid \\
\hline & & 9 & 0.371 & Valid \\
\hline & \multirow{3}{*}{ Pereedaran udara } & 10 & 0.535 & Valid \\
\hline & & 11 & 0.542 & Valid \\
\hline & & 12 & 0.337 & Valid \\
\hline & \multirow{3}{*}{ Pewarnaan } & 13 & 0.344 & Valid \\
\hline & & 14 & 0.845 & Valid \\
\hline & & 15 & 0.401 & Valid \\
\hline
\end{tabular}

Sumber: Output For Windows Release 19.0, 2017

Berdasarkan hasil uji validitas yang telah dilakukan, diketahui bahwa semua item pernyataan untuk variabel lingkungan kerja fisik dalam kuesioner yang digunakan pada penelitian ini semuanya valid. 
Tabel 3 Hasil Uji Validitas Variabel Lingkungan Kerja Non Fisik

\begin{tabular}{|c|l|c|c|c|}
\hline Variabel & \multicolumn{1}{|c|}{ Indikator } & $\begin{array}{c}\text { No. } \\
\text { Item }\end{array}$ & $\begin{array}{c}\text { Corrected Item-Total } \\
\text { Correlation }\end{array}$ & $\begin{array}{c}\text { Status } \\
\text { Item }\end{array}$ \\
\hline \multirow{2}{*}{$\begin{array}{c}\text { Lingkungan Kerja Non } \\
\text { Fisik Kerja (X2) }\end{array}$} & $\begin{array}{l}\text { Hubungan kerja } \\
\text { antara atasan } \\
\text { dan bawahan }\end{array}$ & 16 & 0.524 & Valid \\
\cline { 2 - 5 } & 17 & 18 & 0.362 & Valid \\
\cline { 2 - 5 } & $\begin{array}{l}\text { Hubungan kerja } \\
\text { antara sesama } \\
\text { rekan kerja }\end{array}$ & 19 & 0.584 & Valid \\
\cline { 2 - 5 } & 20 & 21 & 0.736 & Valid \\
\cline { 2 - 5 } & & & 0.612 & Valid \\
\hline
\end{tabular}

Sumber: Output For Windows Release 19.0, 2017

Berdasarkan hasil uji validitas yang telah dilakukan, diketahui bahwa semua item pernyataan untuk variabel lingkungan kerja non fisik kerja dalam kuesioner yang digunakan pada penelitian ini semuanya valid.

Tabel 4 Hasil Uji Validitas Variabel Kinerja

\begin{tabular}{|c|c|c|c|c|}
\hline Variabel & Indikator & No. Item & $\begin{array}{c}\text { Corrected Item-Total } \\
\text { Correlation }\end{array}$ & Status Item \\
\hline \multirow{12}{*}{ Kinerja (Y) } & \multirow{3}{*}{ Kualitas kerja } & 22 & 0.400 & Valid \\
\hline & & 23 & 0.329 & Valid \\
\hline & & 24 & 0.686 & Valid \\
\hline & \multirow{3}{*}{$\begin{array}{l}\text { Kuantitas } \\
\text { kerja }\end{array}$} & 25 & 0.531 & Valid \\
\hline & & 26 & 0.336 & Valid \\
\hline & & 27 & 0.690 & Valid \\
\hline & \multirow{3}{*}{$\begin{array}{l}\text { Pelaksanaan } \\
\text { tugas }\end{array}$} & 28 & 0.717 & Valid \\
\hline & & 29 & 0.534 & Valid \\
\hline & & 30 & 0.840 & Valid \\
\hline & \multirow{3}{*}{$\begin{array}{c}\text { Tanggung } \\
\text { jawab }\end{array}$} & 31 & 0.715 & Valid \\
\hline & & 32 & 0.765 & Valid \\
\hline & & 33 & 0.508 & Valid \\
\hline
\end{tabular}

Sumber: Output For Windows Release 19.0, 2017

Berdasarkan hasil uji validitas yang telah dilakukan, diketahui bahwa semua item pernyataan untuk kinerja dalam kuesioner yang digunakan pada penelitian ini semuanya valid.

Tabel 5 Hasil Uji Reliabilitas Variabel Penelitian

\begin{tabular}{|l|c|c|}
\hline \multicolumn{1}{|c|}{ Variabel } & Crombach's alpha & Keterangan \\
\hline Lingkungan Kerja Fisik (X1) & 0,920 & Reliabel \\
\hline Lingkungan Kerja Non Fisik (X2) & 0,808 & Reliabel \\
\hline Kinerja (Y) & 0,878 & Reliabel \\
\hline
\end{tabular}

Sumber: Output For Windows Release 16.0, 2017

Berdasarkan hasil uji reliabilitas yang telah dilakukan, diketahui bahwa semua variabel mempunyai koefisien Cronbach's Alpha $\geq 0,70$, sehingga dapat disimpulkan bahwa semua variabel penelitian reliabel. Masalah-masalah dalam pengujian model regresi dalam penelitian ini dapat diatasi dengan 
menggunakan model pengujian klasik yaitu dengan uji normalitas, uji multikoliniertas dan uji heterokedastisitas. Uji normalitas bertujuan menguji apakah dalam model regresi, variabel pengganggu atau residual memiliki distribusi normal. Uji multikoliniertas bertujuan untuk menguji apakah model regresi ditemukan adanya korelasi antara variabel bebas (independen). Uji heterokedastisitas dilakukan untuk menguji apakah dalam sebuah model regresi terjadi ketidaksesuaian varians dari residual (variabel gangguan) dari satu pengamatan ke pengamatan yang lain.

Metode analisis yang digunakan dalam penelitian ini ialah melalui penggunaan alat analisis statistik regresi liniear berganda (Multiple Linear Regression) menurut Rangkuti (2006:165) dapat digambarkan sebagai berikut:

$\mathrm{Y}=\mathrm{a}+\mathrm{b}_{1} \mathrm{X}_{1}+\mathrm{b}_{2} \mathrm{X}_{2}+\mathrm{bnXn}+\mathrm{e}$

Keterangan:

$\mathrm{Y} \quad=$ Kinerja Pegawai

$\mathrm{X}_{1} \quad$ = Lingkungan Kerja Fisik

$\mathrm{X}_{2} \quad=$ Lingkungan Kerja Non Fisik

a $\quad=$ Konstanta

$\mathrm{b}_{1}, \mathrm{~b}_{2}=$ Nilai Koefisien Regresi

e $\quad=$ Eror

Ghozali (2011: 98) mengumakakan Uji statistik F pada dasarnya menunjukan apakah semua variabel indenpenden atau bebas yang dimasukan dalam model mempunyai pengaruh secara bersamasama terhadap variabel dependen/terikat. Untuk menguji hipotesis ini digunakan statistik F dengan kriteria pengambilan keputusan sebagai berikut :Dengan menggunakan angka probabilitas signifikansi Apabila probabilitas signifikasi $>0.05$ maka Ho diterima dan Ha ditolak.

1. Apabila probabilitas $>0.05$ maka Ho ditolak dan Ha diterima.

Ghozali (2011:98) mengemukakan Uji parsial (uji t) pada dasarnya menunjukan seberapa jauh pengaruh satu variabel penjelas / independen secara individual dalam menerangkan variasi variabel dependen. Dasar pengambilan keputusan: menggunakan angka probabilitas signifikan dengan tingkat signifikansi 95\% $(\alpha=5 \%)$.

2. Apabila angka probabilitas signifikansi $<0.05$ maka Ho ditolak dan Ha diterima, artinya:

a. Terdapat pengaruh signifikan (secara parsial) dari variabel lingkungan kerja fisik (X1) terhadap kinerja pegawai (Y) pada pegawai Kantor Kementerian Agama Kota Palu.

b. Terdapat pengaruh signifikan (secara parsial) dari variabel lingkungan kerja non fisik (X2) terhadap kinerja pegawai pada pegawai Kantor Kementerian Agama Kota Palu.

3. Apabila Angka probabilitas signifikan $>0.05$ maka Ho diterima dan Ha ditolak. Artinya:

a. Tidak terdapat pengaruh signifikan (secara parsial) dari variabel lingkungan fisik (X1) terhadap kinerja pegawai (Y) pada pegawai Kantor Kementerian Agama Kota Palu.

b. Tidak terdapat pengaruh signifikan (secara parsial) dari variabel lingkungan non fisik (X2) terhadap kinerja pegawai (Y) pada pegawaim Kantor Kementerian Agama Kota Palu. 


\section{HASIL DAN PEMBAHASAN}

Penelitian ini jenis kelamin dikelompokan menjadi dua yaitu laki-laki dan perempuan, pengelompokan tersebut dapat dilihat pada tabel berikut:

Tabel 6 Deskripsi Responden Berdasarkan Jenis Kelamin

\begin{tabular}{|c|c|c|c|}
\hline \multirow{2}{*}{ Valid } & Identitas Responden & Frequency & Percent \\
\cline { 2 - 4 } & Laki-laki & 20 & $40 \%$ \\
\cline { 2 - 4 } & Perempuan & 30 & $60 \%$ \\
\cline { 2 - 4 } & Total & 50 & $100 \%$ \\
\hline
\end{tabular}

Sumber: Data Kuesioner Diolah Kembali, 2017

Berdasarkan kategori jenis kelamin,dapat dikatakan bahwa sebagian besar respondedn didominasi oleh jenis kelamin perempuan sebesar $60, \%$, dan laki-laki sebesar 40,\%, dari hasil tersebut dapat terlihat bahwa sebagian besar pegawai yang bekerja di Kementerian Agama Kota Palu adalah kaum wanita. Hal ini disebabkan karena proporsi kerja lebih banyak membutuhkan wanita seperti mengenai pelayanan haji dan umrah maupun bidang administrasi dan keuangan, sedangkan tenaga kerja laki-laki sebagian besar dibutuhkan untuk aktivitas yag berkaitan dengan observasi lapangan.

Pendidikan merupakan indikator yang mencerminkan kemampuan seseorang untuk dapat menyelesaikan suatu pekerjaan, dengan latar belakang pendidikan pula seseorang dianggap akan mampu menduduki suatu jabatan tertentu. Hasil penelitian yang dilakukan dengan jumlah 50 responden, diperoleh karakteristik responden berdasarkan pendidikan terakhir sebagaimana terlihat dalam Tabel 7 sebagai berikut:

Tabel 7

Karakteristik Responden Berdasarkan Pendidikan Terakhir dan Jenis Kelamin

\begin{tabular}{|c|c|c|c|c|c|}
\hline \multirow{2}{*}{$\begin{array}{c}\text { Tingkat } \\
\text { Pendidikan }\end{array}$} & \multicolumn{2}{|c|}{ Jenis Kelamin } & \multirow{2}{*}{} & \multirow{2}{*}{} \\
\cline { 2 - 6 } & L & P & \multirow{2}{*}{ Frequency } & Percent \\
\hline \multirow{3}{*}{ Valid } & SMA & 9 & 8 & 17 & $34 \%$ \\
\cline { 2 - 6 } & D3 & 1 & 2 & 3 & $6 \%$ \\
\cline { 2 - 6 } & S1 & 10 & 20 & 30 & $60 \%$ \\
\cline { 2 - 6 } & Total & 20 & 30 & 50 & $100 \%$ \\
\hline
\end{tabular}

Sumber: Olah Data 2017

Berdasarkan data yang diperoleh, diketahui bahwa sebagian besar responden memiliki pendidikan setingkat S1 yaitu sebesar 30,\%, kemudian disusul pegawai dengan tingkat pendidikan SMA sebanyak 17,\%, lalu diikuti oleh pegawai dengan tingkat pendidikan D3 sebanyak 3,\%.Kantor Kemenerian Agama Kota Palu didominasi pegawai berpendidikan S1, hal ini dikarenakan untuk menyesuaikan pekerjaan dengan tingkat pendidikan pegawainya. Sebagai contoh untuk pegawai yang berpendidikan S1 ditugaskan untuk menjadi ketua dalam setiap divisi misalnya ketua pendidkan agama islam, ketua pelayanan haji dan umrah, haruslah memiliki latar belakang pendidikan yang tinggi. 
Data responden berdasarkan usia dikelompokan menjadi enam yaitu 18-25 tahun, 26-35 tahun, 3645 tahun, 46-55 tahun, 56-65 tahun, 66-75 tahun, pengelompokan tersebut dapat dilihat pada tabel berikut:

Tabel 8 Deskripsi Responden Berdasarkan Usia dan Jenis Kelamin

\begin{tabular}{|c|c|c|c|c|c|}
\hline \multirow{2}{*}{ Tingkat Usia } & \multicolumn{2}{|c|}{ Jenis kelamin } & \multirow{2}{*}{} & \multirow{2}{*}{ Frequency } & Percent \\
\cline { 2 - 6 } & $\mathrm{L}$ & $\mathrm{P}$ & Frequency & $6 \%$ \\
\cline { 2 - 6 } & $18-25$ & 1 & 2 & 3 & $54 \%$ \\
\cline { 2 - 6 } & $26-35$ & 10 & 17 & 27 & $32 \%$ \\
\cline { 2 - 6 } & $36-45$ & 6 & 10 & 16 & $8 \%$ \\
\cline { 2 - 6 } & $46-55$ & 3 & 1 & 4 & $100 \%$ \\
\cline { 2 - 6 } & Total & 20 & 30 & 50 & \\
\cline { 2 - 6 } & & & & \\
\end{tabular}

Sumber: Data Kuesioner Diolah Kembali, 2017

Berdasarkan Tabel 5.3 diatas, dapat disimpulkan bahwa usia pegawai yang paling dominan yaitu 26-35 tahun yaitu 54\%. Hal ini menggambarkan bahwa dalam sebuah inatansi sangat diperlukan pegawai yang memiliki semangat dan jiwa kerja yang tinggi.

Menurut Ghozali (2005:111), uji normalitas bertujuan untuk menguji apakah dalam suatu model regresi linear variabel terikat dan variabel bebas keduanya mempunyai distribusi normal atau tidak. Model regresi yang baik adalah memiliki distribusi data normal atau mendekati normal. Untuk mendeteksi normalitas data dapat dilakukan dengan pengujian berikut:

1. Jika data menyebar di sekitar garis diagonal dan mengikuti arah garis diagonal, maka model regresi memenuhi asumsi normalitas.

2. Jika data menyebar jauh dari diagonal dan atau tidak mengikuti arah garis diagonal, maka model regresi tidak memenuhi asumsi normalitas.

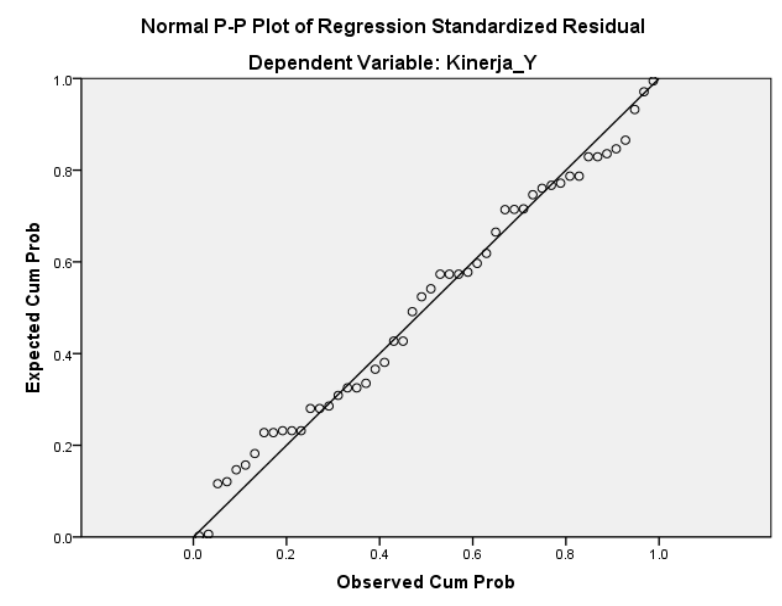

Gambar 1

Gambar 1 di atas dapat dilihat bahwa pengujian data dengan menggunakan bantuan program statistik SPSS For Windows Release 19.0, diperoleh data hasil penelitian cenderung tersebar mendekati atau sekitar garis diagonal dan mengikuti arah garis diagonal sehingga asumsi normalitas dapat dikatakan terpenuhi.

Untuk mengetahui ada tidaknya multikolinieritas, maka diuji dengan menghitung nilai Tolerance Value dan lawannya Variance Inflation Factor (VIF), dengan bantuan software computer SPSS for windows release 16.0. Nilai cut off yang umum dipakai untuk menunjukkan adanya multikolonieritas 
adalah Tolerance value $<0,10$ atau sama dengan nilai VIF $>10$ (Ghozali, 2005:91). Adapun hasil uji multikolonieritas dari penelitian ini dapat dilihat pada tabel berikut ini:

Tabel 9 Hasil Pengujian Multikolinearitas

\begin{tabular}{|l|c|c|c|}
\hline \multirow{2}{*}{\multicolumn{1}{|c|}{ Variabel Independen }} & \multicolumn{2}{c|}{ Collinierity Statistic } & \multirow{2}{*}{ Keterangan } \\
\cline { 2 - 3 } & Tolerance & VIF & \\
\hline Lingkungan kerja fisik & 0.892 & 1.121 & \multirow{2}{*}{ Non Multikolinieritas } \\
\hline Lingkungan kerja non fisik & 0.892 & 1.121 & Non Multikolinieritas \\
\hline
\end{tabular}

Sumber: Output For Windows Release 16.0, 2017

Berdasarkan hasil uji multikolonieritas yang di lakukan, dapat diketahui bahwa nilai Tolerance value yang diperoleh $<0,10$ dan nilai $\mathrm{VIF}<10$. Dengan demikian dapat disimpulkan bahwa dalam penelitian ini tidak terjadi multikolinearitas.

Uji heteroskedastisitas dilakukan untuk mengetahui apakah dalam regresi terdapat ketidaksamaan variance dari residual satu pengamatan ke pengamatan yang lain tetap atau homoskedastisitas.

Hasil pengujian dengan menggunakan analisis grafik dapat dilihat pada pada gambar berkut ini:

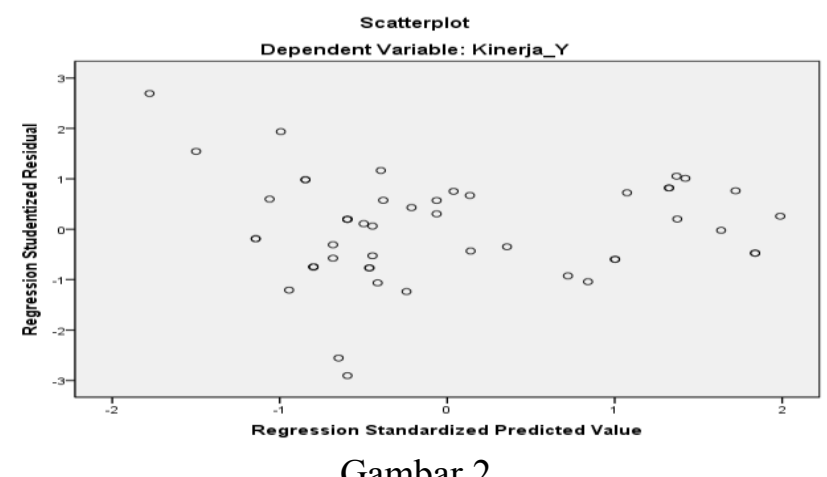

Sumber: Output For Windows Release 19.0, 2017

Dari gambar 2 di atas dapat dilihat bahwa tidak ada pola yang jelas, titik-titik yang menyebar di atas dan di bawah angka 0 pada sumbu $Y$, sehingga dapat disimpulkan bahwa pada model regresi tidak terjadi masalah heterokedastisitas.

\section{Uji Regresi Linear Berganda}

Penelitian ini bertujuan untuk mengetahui besarnya pengaruh secara simultan dan parsial antara lingkungan kerja fisik dan lingkungan kerja non fisik terhadap kinerja pegawai di Kementerian Agama Kota Palu. Untuk menguji kebenaran hipotesis yang diajukan dalam penelitian ini, menggunakan metode analisis regresi linear berganda. Sementara itu untuk menguji permasalahan dan hipotesis pertama yang telah dirumuskan digunakan uji $\mathrm{F}$, sedangkan untuk menguji permasalahan dan hipotesis kedua digunakan uji t, dengan menggunakan program SPSS For Windows Release 19.0. Adapun hasil analisis tersebut dapat dilihat sebagai berikut:

Tabel 10 Hasil Perhitungan Regresi Linear Berganda Coefficients $^{\mathrm{a}}$

\begin{tabular}{|c|c|c|c|c|c|c|}
\hline & \multirow[b]{2}{*}{ Model } & \multicolumn{2}{|c|}{ Unstandardized Coefficients } & \multirow{2}{*}{$\begin{array}{c}\text { Standardized } \\
\text { Coefficients }\end{array}$} & \multirow[b]{2}{*}{$\mathrm{T}$} & \multirow[b]{2}{*}{ Sig. } \\
\hline & & B & Std. Error & & & \\
\hline No. & (Constant) & 1.673 & .430 & & 3.896 & .000 \\
\hline
\end{tabular}




\begin{tabular}{|c|c|c|c|c|c|c|}
\hline 1. & $\begin{array}{c}\text { Lingkungan keja fisik } \\
\text { (X1 }\end{array}$ & 189 & .067. & .332 & 2.815 & .007 \\
\hline \multirow[t]{3}{*}{2.} & $\begin{array}{l}\text { Lingkungan kerja non } \\
\text { fisik (X2) }\end{array}$ & .395 & 102 & .457. & 3.874 & .000 \\
\hline & \multicolumn{3}{|l|}{ Multiple R } & \multicolumn{3}{|c|}{ F- hitung } \\
\hline & R Square $\left(\mathrm{R}^{2}\right)$ & \multicolumn{2}{|c|}{$=0,418$} & Sig & \multicolumn{2}{|c|}{$=0,000$} \\
\hline
\end{tabular}

Sumber: Output For Windows Release 19.0, 2017

Berdasarkan nilai dari tabel diatas, maka persamaan regresi linear berganda dapat dirumuskan sebagai beriku:

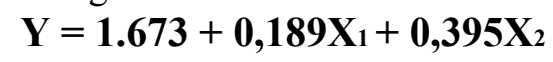

Berdasarkan persamaan tersebut maka dapat dinyatakan bahwa variabel independen (X1 dan X2) memberi pengaruh positif terhadap variabel dependen (Y): (1) Nilai konstanta (a) adalah 1,673, artinya apabila variabel lingkungan kerja fisik (X1) dan lingkungan kerja non fisik (X2) nilainya 0 , maka kinerja pegawai Kantor Kementerian Agama Kota Palu tetap positif 1,673: (2) Nilai koefisien regresi variabel lingkungan kerja fisik (X1) bernilai positif yaitu 0,332. Hal ini menyatakan bahwa nilai lingkungan kerja fisik meningkat maka akan meningkatkan kinerja pegawai Kementerian Agama Kota : (3) PaluNilai koefisien regresi variabel lingkungan kerja non fisik (X2) bernilai positif yaitu 0,457. Hal ini menyatakan bahwa nilai lingkungan kerja non fisik meningkat maka akan meningkatkan kinerja pegawai Kementerian Agama Kota Palu. Untuk mengetahui pengaruh signifikan secara srempak maupun secara parsial dari variabel independen terhadap variabel dependen, maka digunaka uji F dan uji t. Penjelasan lebih lengkapnya akan dijelaskan dibawah.

Uji F bertujuan untuk mengetahui apakah variabel independen yakni lingkungan kerja fisik dan lingkungan kerja non fisik yang diteliti memiliki pengaruh secara serempak terhadap variabel dependen yakni kinerja pegawai Kementerian Agama Kota Palu. Untuk lebih jelasnya dapat dilihat pada tabel berikut:

Tabel 11 Hasil Pengujian Serempak (Uji F)

ANOVA $^{b}$

\begin{tabular}{|c|c|c|c|c|c|c|}
\hline \multicolumn{2}{|c|}{ Model } & Sum of Squares & Df & Mean Square & F & Sig. \\
\hline 1 & Regression & 3.116 & 2 & .558 & 16.857 & $.000^{\mathrm{a}}$ \\
\cline { 2 - 7 } & Residual & 4.344 & 47 & .092 & & \\
\cline { 2 - 7 } & Total & 7.459 & 49 & & & \\
\hline
\end{tabular}

Sumber: Output For Windows Release 19.0, 2017

Berdasarkan hasil uji regresi pada tabel di atas, diperoleh Sig.F sebesar $0,000<0,05$, yang dapat diartikan bahwa variabel lingkungan kerja fisik kerja dan lingkungan kerja non fisik secara serempak berpengaruh signifikan terhadap variabel kinerja pegawai. berdasarkan hasil tersebut dapat disimpulkan bahwa $\mathrm{H}_{0}$ ditolak dan $\mathrm{H}_{\mathrm{a}}$ diterima.

\section{Uji t (Pengujian Hipotesis Secara Parsial)}

Uji t digunakan untuk mengetahui apakah variabel independen yakni lingungan kerja fisik dan lingkungan kerja non fisik yang diteliti memiliki pengaruh secara parsial terhadap variabel dependen 
yakni kinerja pegawai Kementerian Agama Kota Palu. Untuk lebih jelasnya dapat dilihat pada tabel berikut :

Tabel 12 Hasil Pengujian Parsial (Uji t)

Coefficients $^{\mathrm{a}}$

\begin{tabular}{|c|c|c|c|c|c|c|}
\hline & & \multicolumn{2}{|c|}{ Unstandardized Coefficients } & \multirow{2}{*}{$\begin{array}{c}\text { Standardized } \\
\text { Coefficients } \\
\text { Beta }\end{array}$} & \multirow[b]{2}{*}{$\mathrm{T}$} & \multirow[b]{2}{*}{ Sig. } \\
\hline \multicolumn{2}{|c|}{ Model } & B & Std. Error & & & \\
\hline \multirow{3}{*}{1} & (Constant) & 1.673 & .430 & & 3.896 & .000 \\
\hline & $\mathrm{X} 1$ & .189 & .067 & .332 & 2.815 & .007 \\
\hline & $\mathrm{X} 2$ & .395 & .102 & .457 & 3.874 & .000 \\
\hline
\end{tabular}

Uji t dilakukan dengan membandingkan nilai t signifikansi lebih kecil dari $\alpha 0,05$ maka dapat dipastikan bahwa variabel independen berpengaruh signifikan terhadap variabel dependen, sebaliknya jika nilai t signifikansi lebih besar dari $\alpha 0,05$ maka dapat dipastikan bahwa variabel independen berpengaruh tidak signifikan terhadap variabel dependen, dapat dijelaskan hasil uji t dari variabel independen adalah sebagai berikut:

a. Lingkungan kerja fisik (X1)

Variabel lingkungan kerja fisik memiliki tingkat signifikansi t sig. $(0,007)<\alpha(0,05)$. Hal ini menunjukkan bahwa hipotesis yang menyatakan "lingkungan kerja fisik secara parsial berpengaruh signifikan terhadap kinerja pegawai Kementerian Agama Kota Palu" terbukti atau bahwa $\mathrm{H}_{0}$ ditolak dan $\mathrm{H}_{\mathrm{a}}$ diterima.

b. Lingkungan kerja non fisik (X2)

Variabel lingkungan kerja non fisik memiliki tingkat signifikansi t sig. $(0.000)<\alpha(0,05)$. Hal ini menunjukkan bahwa hipotesis yang menyatakan "lingkungan kerja non fisik secara parsial berpengaruh signifikan terhadap kinerja pegawai Kementerian Agama Kota Palu" terbukti atau bahwa $\mathrm{H}_{0}$ ditolak dan $\mathrm{H}_{\mathrm{a}}$ diterima.

\section{Pembahasan Hasil Penelitian}

\section{Lingkungan Kerja Fisik (X1) dan Lingkungan Kerja Non Fisik (X2) terhadap Kinerja Pegawai (Y)}

Berdasarkan hasil uji $\mathrm{F}$ yang dilakukan, menunjukkan hasil bahwa lingkungan kerja fisik dan lingkungan kerja non fsik secara serempak berpengaruh signifikan terhadap kinerja pegawai. Hasil ini menggambarkan bahwa semakin baik diciptakanya lingkungan kerja fisik dan lingkungan kerja non fisik maka akan menciptakan suatu kondisi kerja yang menyenangkan dalam sebuah instansi, pegawai yang mersa senanag dan nyaman dalam bekerja akan lebih semangat dan bertanggung dalam bekerja sehingga kinerja yang di hasilkan oleh pegawai sesuai dengan apa yang diinginkan oleh instansi. Sunyoto (2012), mengatakan bahwa lingkungan kerja yang baik atatu kondisi kerja yang dapat memberikan rasa nyaman dam menyenangkan dalam bekerja maka akan berpengaruh terhadap semangat pegawai dalam bekerja. Hasil penelitian ini sejalan dengan hasil penelitian yang dilakukan oleh Nela Pima Rahmawati (2014), menyatakan bahwa linkungan kerja fisik dan lingkungan kerja non fisik secara bersama-sama dan secara simultan berpengaruh signifikan terhadap kinerja pegawai. 


\section{Lingkungan Kerja Fisik Berpengaruh Terhadap Kinerja Pegawai}

Berdasarkan hasil penelitian yang telah dilakukan pada Kantor Kementerian Agama Kota Palu diketahui bahwa variabel lingkungan kerja fisik berpengaruh signifikan secara parsial terhadap kinerja pegawai. Hal ini dapat dilihat dari hasil uji t yang menunjukkan bahwa tingkat signifikansi t sig yang diperoleh sebesar $0,007<\alpha 0,05$. Hal tersebut menunjukkan bahwa semakin baik lingkungan kerja fisik, maka akan menciptakan suatu pekerjaan yang menyenangkan untuk dikerjakan, sehingga akan menimbulkan semangat kerja pegawai. Pengaruh lingkungan kerja fisik terhadap Kementerian Agama Kota Palu bernilai positif artinya jika lingkungan kerja fisik meningkat maka akan meningkatkan kinerja pegawai Kementerian Agama Kota Palu. Hal ini menyatakan bahwa variabel lingkungan kerja fisik merupakan faktor penting dalam peningkatan kinerja pegawai. Karena dengan terciptanya lingkungan kerja fisik yang baik dan nyaman maka akan membuat pegawai merasa senang, nyaman, dan betah bekerja sehingga pegawai semangat dalam bekerja serta dapat melaksanakan tugasnya dengan baik dan dengan demikian akan mempermudah Kementerian Agama Kota Palu dalam mencapai tujuannya. Menurut Sarwono (2005) Lingkungan Kerja Fisik adalah tempat kerja pegawai melakukan aktivitasnya dimana lingkunga kerja fisik mempengaruhi semangat dan emosi kerja para pegawai. Hal ini sejalan dengan penelitian yang dilakukan oleh Rahmawati (2014) yang menyatakan bahwa variabel lingkungan kerja fisik berpengauh signifikan terhadap kinerja pegawai.

\section{Linkungan Kerja Non Fisik Berpengaruh Terhadap Kinerja Pegawai}

Berdasarkan hasil penelitian yang telah dilakukan pada kantor Kementerian Agama Kota Palu diketahui bahwa variabel lingkungan kerja non fisik berpengaruh signifikan secara parsial terhadap kinerja pegawai Kementerian Agama Kota Palu. Hal ini dapat dilihat dari hasil uji t yang menunjukkan bahwa tingkat signifikansi t sig yang diperoleh sebesar $0,000<\alpha 0,05$. Hal tersebut menunjukkan bahwa semakin baik lingkungan kerja non fisik, maka akan menciptakan suasana kerja yang menyenangkan sehingga akan meningkatkan semangat dan kinerja yang baik dari pegawai.

Hubungan kerja yang terjalin dengan baik sangat mempengaruhi kinerja seorang pegawai hal ini sejalan dengan pendapat yang dikemukakan oleh Nitisemito (2001), sebuah organisasi dapat mencerminkan kondisi yang mendukung kerjasama antara tingkat atasan, bawahan maupun yang memiliki status jabatan yang sama didalam sebuah perusahaan atau kantor. Kondisi yang hendak diciptakan adalah suasana kekeluargaan, komunakasi yang baik, dan pengendalian diri. Membina hubungan yang baik antara sesana rekan kerja, bawahan naupun atasan harus dilakukan karena kita saling membutuhkan. Hubungan kerja yang terbentuk sangat mempengaruhi psikologis pegawai.

\section{KESIMPULAN DAN SARAN}

\section{Kesimpulan}

Berdasarkan dari hasil analisis dan pembahasan yang dilakukan, maka dapat disimpulkan sebagai berikut:

1. Lingkungan Kerja Fisik (X1) dan Lingkungan Kerja Non Fisik (X2) secara serempak berpengaruh positif dan signifikan terhadap kinerja pegawai (Y) pada Kementerian Agama Kota Palu.

2. Lingkungan Kerja Fisik (X1) berpengaruh positif dan signifikan terhadap Kinerja Pegawai (Y) pada Kementerian Agama Kota Palu.

3. Lingkungan kerja non fisik (X2) berpengaruh positif dan signifikan terhadap kinerja (Y) pegawai pada Kementerian Agama Kota Palu. 


\section{Saran}

Berdasarkan dari hasil analisa dan kesimpulan yang dilakukan, maka beberapa saran yang dapat diberikan adalah sebagai berikut:

1. Pentingnya meningkatkan suasana lingkunagn kerja yang baik dan kondusif dalam membantu meningkatkan produktivitas pegawai. Pihak instansi tetap meningkatkan kondisi dan keadaan lingkungan kerja fisik maupun non fisik pada Kementerian Agama Kota Palu, misalnya memperhatikan keadaan ruangan tentunya keadaan ruangan atau tata ruang yang dapat memenuhi kapasitas sebagai penyimpanan berkas pegawai maupun perlengkapan kantor sehingga penataan peralatan kantor dapat tertata dengan baik, banyaknya data-data pegawai pada Kementerian Agama Kota palu sebaiknya disimpan dalam bentuk file pada komputer selain mempermudah proses kerja pegawai namun juga tidak membuat ruangan terasa padat diakibatkan oleh berkasberkas data pegawai. Selain itu lebih memperhatikan tingkat kebisingan kantor agar tidak mengganggu kinerja pegawai lainyya.

2. Pada lingkungan kerja non fisik yang merupakan hubungan kerja antar sesama pegawai, baik hubungan pegawai terhadap atasan maupun hubungan sesama pegawai yaitu selaras dan serasi yang penuh kekeluargaan serta hubungan kerja yang positif tentu saja dapat meningkatkan kinerja pegawai. Kegiatan seperti silahturahmi atau tamasya dapat mempererat huungan kekeluargaan.

3. Pada variabel kinerja pegawai yang merupakan hasil kerja atau pencapaian pegawai terhadap suatu pekerjaan, untuk menghasilkan kualitas kerja pegawai sebaiknya dilakukan pelatihan dan pengembangan pada setiap waktu yang telah ditentukan agar kinerja pegawai dapat meningkat dengan hasil pengetahuan yang lebih banyak lagi. Selain itu sebaiknya ada team penilaian terhadap setiap pegawai yang mengikuti pelatihan dan pengembangan agar dapat diketahui pegawai yang kinerjanya baik dan kinerja pegawai yang lalai.

4. Diharapkan kepada peneliti selanjutnya agar menggunakan variabel lain yang dapat mempengaruhi kinerja pegawai, sehingga dapat memberikan manfaat maupun pembelajaran kepada pihak yang berkepentingan.

\section{REFERENSI}

Ahmad,Tohardi. (2002). Pemahaman Praktis Manajemen Sumber Daya Manusia. Universitas Tanjung Pura. Mandar Maju:Bandung.

Anwar, Prabu ,Mangkunegara. (2005). Sumber Daya Manusia Perusahaan. Remaja Rosdaya karya: Bandung.

Ghozali, Imam. (2005) . Aplikasi Analisis Multi Variate Dengan Program Ibm Spss 19 ( Edisi Kelima. ).Unversitas Diponegoro: Semarang.

Hasibuan, Malayu. (2012). Manajemen Sumber Daya Manusia. PT. Bumi Aksara:Jakarta.

Handoko, T Hani. (1999). Manajemen. BPFE: Yokyakarta.

Ishak, Hendri dan Tanjung. (2003). Manajemen Sumber Daya Manusia.Universitas Trisakti:Jakarta

Lewa, dan Subono. (2005). Pemgaruh Kepemimpinan, Lingkungan Kerja Fisik, Dan Kompensasi

Terhadap Kinerja Karyawan Di PT. Pertamina (PERSERO) Daerah Operasi Hulu Jawa Bagian Barat. Sinergi Khusus On Human Resources: Cirebon.

Mangkunegara, A.A. Anwar Prabu. (2001). Manajemen Sumber Daya Manusia Perusahaan. Bandung :Remaja Rosda Karya

Mangkunegara, A.A. Anwar Prabu. (2004). Manajemen Sumber Daya Manusia Perusahaan. Bandung: Remaja Rosda Karya

Mangkunegara, A.A. Anwar Prabu. (2005). Manajemen Sumber Daya Manusia Perusahaan.Bandung: Remaja Rosda Karya 
Melinda, T. (2007). Konsentrasi Manajemen Sumber Daya Manusia ( Perencanaan Sumber Daya Manusia, Evaluasi Kinerja, Budaya Organisasi). Cetakan Pertama STIE Mahardhika: Surabaya

Nitisemito, S. Alex. (2000). Manajemen Personalia. Ghalia Indonesia: Jakarta.

Rahmawati, Swasto, dan Prasetya. (2014). Pengaruh Lingkungan Kerja Terhadap Kinerja Karyawan Pada Kantor Pelayanan Pajak Pratama Malang Uatara. Jurnal Administrasi Bisni (JAB) Vol.8 No.2. 1-9.

Sarwono, Sarlito Wirawan (2005). Pisokologi Lingkungan. Penerbit PT. Jakarta: . Gramedia Grasindo Saydam, G. (2002). Manajemen Sumber Daya Manusia (Human Resources Managemen).Jakarta: Djambatan

Sihombing, Umberto.(2004). Pengaruh Keterlibatan Dalam Pengambilan Keputusan, Penilaian Pada Lingkungan Kerja Dan Motivasi Berpretasi Terhadap Kepuasan Kerja. Jakarta:Pamong Praja

Sugiyono. (2012). Metode Penelitian Administrasi.Bandung: Alfabeta . (2013). Metode Penelitian Administrasi. Bandung: Alfabeta . (2016). Metode Penelitian Administrasi. Bandung: Alfabeta

Sukamto, Masjaya, dan Riady .(2013). Pengaruh Lingkungan Kerja Fisik dan Non Fisik Terhadap Kinerja Pegawai Pada Badan Ketahanan Pangan dan Pelaksana penyuluhan Daerah Kota Samarinda. Ejournal Administrative Reform, Volume 1, No. 2. 431-443.

Sunyoto, Danang. (2012). Manajemen Sumber daya manusia. (1th ed.) C A P S (Center For Academic Publishing Service ):Yogyakarta

Usman, Husaini. (2009). Manajemen Teori, Praktik dan Riset Pendidikan.Jakarta:Bumi Aksara Wursanto, Iganasius. (2009). Dasar-dasar ilmu organisasi. Edisi Dua. Yogyakarta. 